\title{
The Dragon vs. the Eagle \& Serpent: The Economic Impact of China in Mexico
}

\author{
Paul A. Escajadillo \\ Duke University, Fuqua School of Business, Durham, USA \\ Email: paul.escajadillo@fuqua.duke.edu
}

Received 19 July 2014; revised 20 August 2014; accepted 6 September 2014

Copyright (C) 2014 by author and Scientific Research Publishing Inc.

This work is licensed under the Creative Commons Attribution International License (CC BY). http://creativecommons.org/licenses/by/4.0/

(c) (i) Open Access

\begin{abstract}
Although China has become, over the past three decades, an unprecedented case of economic growth accompanied by a voracious appetite for natural resources, China has been increasingly engaging with Latin America. However, as Sino-Latin American relationships have improved Latin American countries' economies through their supply of primary products and through the region's growing importance to China as a market, Mexico has not benefited from this increased engagement. This paper will show that as the balance of trade of selected Latin American countries has grown with China and benefited their economies, it has not been the case with Mexico in particular.
\end{abstract}

\section{Keywords}

Mexico, China, Trade, Latin America

\section{Introduction}

China has become, over the past three decades, an unprecedented case of economic growth with its expected rise to become the world's largest economy by 2030, increased standard of living for most of its citizens, and relatively relaxed government control over their citizens' lives (Starr, 2010). This rise has managed to weather global downturns better than most developed countries' economies; for example, during the height of the worldwide banking crisis in 2008 and 2009 "the Chinese economy carried on growing at a rate of 9.1\%" (Rosales \& Kuwayama, 2012). This high rate of economic expansion has been based on a "development model that combines a modernization of state-led economic organization and regulation with a gradual, controlled liberalization" of the economy and society (Fernández Jilberto \& Hogenboom, 2010). The resulting "economic miracle of market socialism" and its place in the globalized world have been viewed within China as a "peaceful rise" (later amended to "peaceful development" to reflect a less threatening and triumphalist approach) which 
can "serve peace, stability, and common prosperity in the world" (Kissinger, 2011).

The aspiration to obtain this peaceful economic development has been at the heart of all Chinese policy. Domestically, rapid economic growth (i.e., development) that did not threaten the dominance of the Chinese Communist Party was the norm, as all other issues were subordinated to this goal and open to compromise (Starr, 2010). On the international front, China's foreign relations have been centered around three issues: "modernization, nationalism, and regionalism" (Liu, 2004). Viewing modernization as the necessary prerequisite for economic development, it was labeled as the most important of the three, with Deng Xioaping defining it as "the essential condition for solving both our domestic and our external problems” (Liu, 2004).

Thus, with peaceful development at the forefront of all policy decisions, China's economic rise seemed almost inevitable in hindsight. However, this rise has been accompanied by a voracious appetite for resources such as "oil and gas, raw materials and minerals and [access] to foreign markets", in effect driving most of the engagement with the global economy (Dittmer \& Yu, 2010). One of the regions of the global economy that China has been increasingly engaging with has been Latin America, more specifically Mexico, which will be the focus of this paper. It will be shown that as Sino-Latin American relationships have improved Latin American countries' economies through their supply of primary products and through the region's growing importance to China as a market (Ellis, "China in Latin America", 2009), Chinese exports have "pose[d] a clear competitive threat to domestic producers" in Mexico while fomenting "an unbalanced economic model" linked to the volatility of commodity prices (Fornés \& Philip, 2012).

\section{China in Latin America}

Similar to the authoritarian state's shift toward economic opening that occurred in China, several Latin America countries instituted economic neoliberalism through authoritarian state's bureaucracies (Fernández Jilberto \& Hogenboom, 2010). In Mexico, the dictatorship of the Institutional Revolutionary Party (PRI) fomented this substitution of Keynesianism with neoliberalism. Yet for all the political-economic similarities from a half century ago, today's Sino-Mexican relations are nowhere near the perceived peaceful development within China, as they have been more characterized by rivalry than cooperation: Mexico's dominance in manufacturing after the implementation of the North American Free Trade Agreement (NAFTA) has been severely affronted by China. For example, between 1990 and 2003, "over 55\% of Mexican exports to the United States... [were in] those sectors into which Chinese competition has emerged with most force”, causing a large displacement for Mexico in the U.S. market (see Figure 1) (Dittmer \& Yu, 2010). This has caused a growing anti-Chinese sentiment that stands in stark contrast to the growing South-South cooperation occurring in the rest of the region: Latin American officials have "highlight [ed] that mutual understanding and cooperation are greatly facilitated by China's status as a developing country” as the Middle Kingdom understands their countries' needs (Hearn \& LeónManríquez, 2011).

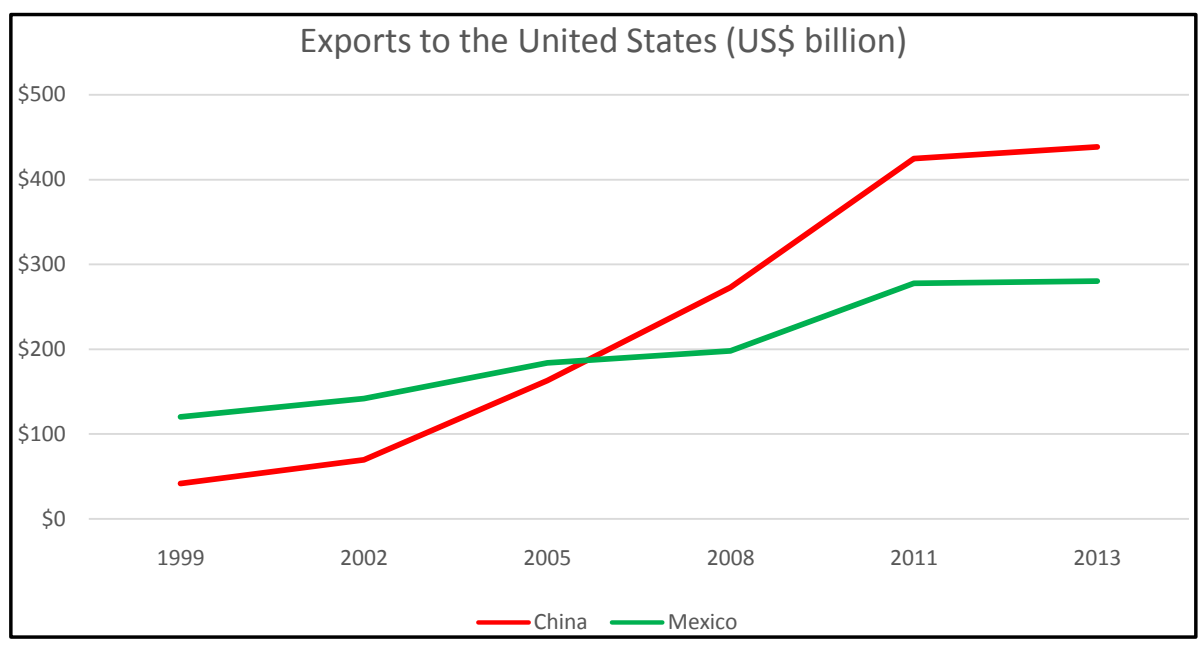

Figure 1. Exports to the United States from China and Mexico, 1999-2013. Source: International Monetary Fund, Direction of Trade Statistics; Office of the United States Trade Representative; United States Census Bureau. Statistics compiled by author. 
Further fomenting the competitive nature of the China-Mexico relationship, "China takes a strikingly small share of Mexico's exports: just 1.0\% of the total in 2009” (Rosales \& Kuwayama, 2012), while Mexico's dependence on China for imports is considerably higher, "as the country buys almost $14 \%$ of all its imported goods and services from China, as compared to $12 \%$ from the European Union”. And while China has conferred upon Mexico the status of strategic partner, a term reserved for a country seen as "more important and having influence over their neighbors” (Ellis, "China’s Strategy in Latin America Demonstrates Boldness of President Xi”, 2014), alongside Argentina, Brazil, and Venezuela, the balance of trade has grown increasingly negative only for Mexico. In the past few years, the trade balances have actually become positive for the other three strategic partners (see Figure 2). However, while Mexico's trade deficit is growing steadily with China when compared to its Latin American neighbors, it still pales in comparison to the U.S. trade deficit (see Figure 3).

As increasing Chinese demand for commodities has driven exports and improved the terms of trade, especially for the petroleum and mineral exporting countries of South America, higher prices for export products have had agreater effect than higher volumes. In the case of Mexico, however, the tendency has been the opposite,

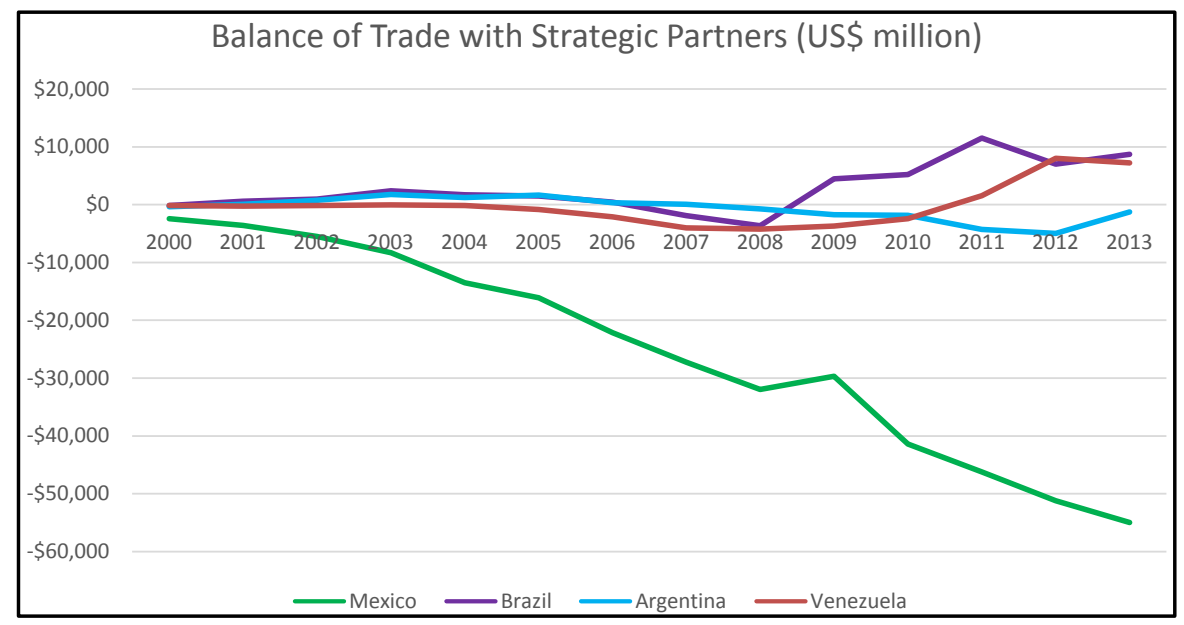

Figure 2. Balance of trade of selected Latin American Countries (strategic partners) with China, 2000-2013. Source: World Integrated Trade Solutions; United Nations Commodity Trade Statistics Database; Subsecretaría de Comercio Exterior de la Secretaría de Economía (Mexico); The Economist; The BBC; Cámara Argentina de Comercio; Asociación Latinoamericana de Integración. Statistics compiled by author.

Balance of Trade Comparison: Mexico and U.S.A. (US\$ million)

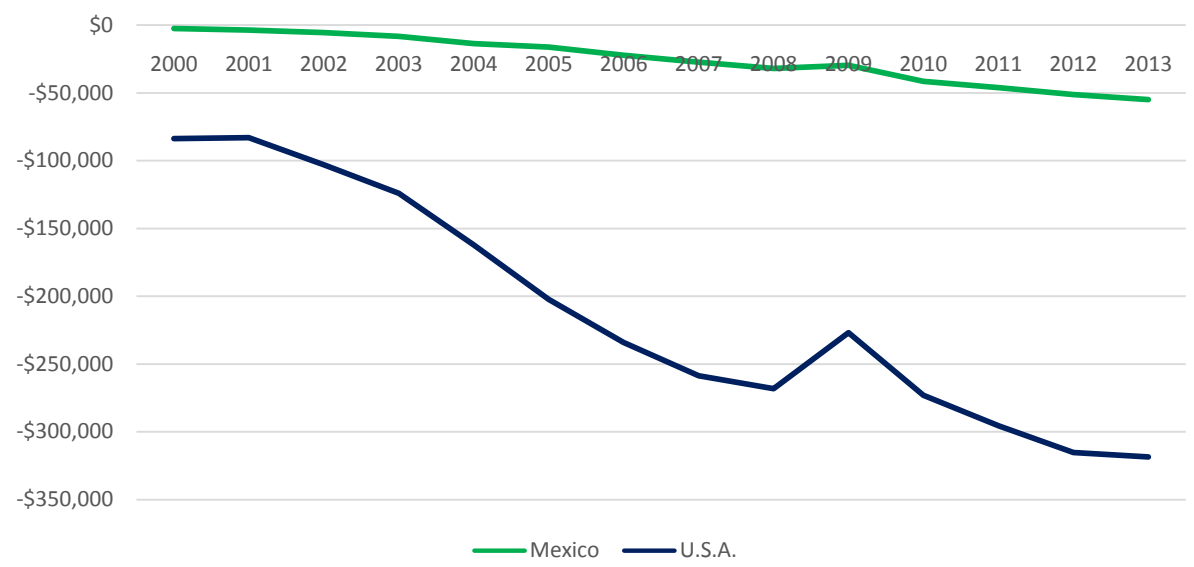

Figure 3. Balance of trade of Mexico and the U.S. with China, 2000-2013. Source: World Integrated Trade Solutions; United Nations Commodity Trade Statistics Database; United States Census Bureau; Subsecretaría de Comercio Exterior de la Secretaría de Economía (Mexico); The Economist. Statistics compiled by author. 
with export volumes increasing more (Rosales \& Kuwayama, 2012). Thus, China’s peaceful rise has come at a high cost for Mexico, a country that became over-reliant on growth through low-cost exports and low-wage labor directly tied to the U.S. economy. This can serve as a cautionary tale for China, especially given the rising labor costs in China and continued increases in transportation costs which affect global supply chains (Cattan \& Martin, 2014). Concerned that in the near future China's continued economic development may suffer due to Mexico's competitive proximity to the U.S., Chinese officials have preemptively begun establishing production facilities in Mexico, "oriented toward exporting goods to the US market under the provisions" of NAFTA (Ellis, "China’s Growing Relationship with Latin America and the Caribbean in the Context of US Policy Toward the Region”, 2014).

\section{Conclusion}

While this paper has examined the effect of China's increasing role in the developing world (Mexico in particular), it cannot leave one issue unexamined: the future of China and the Chinese Communist Party (CCP) and some eerie similarities with Mexican politics of the twentieth century. For example, former Mexican ambassador to China Jorge Guajardo has proposed an argument that China's Communist Party may have more to learn from Mexico's Institutional Revolutionary Party, which ruled the country through extensive patronage in a one-party system from 1929 to 2000, than from the Soviet Union (Wade, 2014). As far as one-party rule heralded by a "socialist" organization that veered centrist in order to begin implementing modernizing policies of neo-liberalism and privatization while in power, the CCP stands to benefit much more from analyzing the successes and downfalls of the PRI's time in power. The similarities between the two parties' responses to student oppositions in Tiananmen Square (1989) and Tlatelolco (1968) are even more pointed. Therefore, even as China's focus on peaceful development has been at the core of its unprecedented rise, mounting governmental corruption and growing public discontent may one day lead to a popularly implemented transition from the CCP to another entity, much as it occurred for Mexico in 2000 with the electoral victory of the long-standing opposition National Action Party (PAN).

In conclusion, the strategic effects in Latin America, and more specifically in Mexico, of China's mounting economic and political power are not entirely clear and there is no certainty "China's march to great power... cannot be derailed” (Betts \& Christensen, 2008) or that the longevity of the CCP is guaranteed.

\section{References}

Betts, R. K., \& Christensen, T. J. (2008). China: Can the Next Superpower Rise Without War? Conflict after the Cold War: Arguments on Causes of War and Peace. New York: Pearson Education, Inc.

Cattan, N., \& Martin, E. (2014). Mexico Replaces China as U.S. Supplier with No Wage Gains: Jobs. Bloomberg News, 14 June 2012.

Dittmer, L., \& Yu, G. T., Eds. (2010). China, the Developing World, and the New Global Dynamic. Boulder, Colorado: Lynne Rienner Publishers, Inc.

Ellis, R. E. (2014). China's Growing Relationship with Latin America and the Caribbean in the Context of US Policy Toward the Region. Air \& Space Power Journal in Chinese, 79-93.

Ellis, R. E. (2014). China’s Strategy in Latin America Demonstrates Boldness of President Xi. The Manzella Report, 19 Febuary 2014.

Ellis, R. E. (2009). China in Latin America. Boulder, Colorado: Lynne Rienner Publishers, Inc.

Fernández Jilberto, A. E., \& Hogenboom, B., Eds. (2010). Latin America Facing China. New York: Berghahn Books.

Fornés, G., \& Philip, A. B. (2012). The China-Latin America Axis. New York: Palgrave Macmillan.

Hearn, A. H., \& León-Manríquez, J. L., Eds. (2011). China Engages Latin America. Boulder, Colorado: Lynne Rienner Publishers, Inc.

Kissinger, H. (2011). On China. New York: The Penguin Press.

Liu, G. L., Ed. (2004). Chinese Foreign Policy in Transition. Hawthorne, New York: Aldine De Gruyter.

Rosales, O., \& Kuwayama, M. (2012). China and Latin America and the Caribbean. Santiago: United Nations Economic Commission for Latin America and the Caribbean.

Starr, J. B. (2010). Understanding China: A Guide to China's Economy, History, and Political Culture. New York: Hill and Wang.

Wade, S. (2014). Is China the Next Mexico? China Digital Times, 23 January 2014. 
Scientific Research Publishing (SCIRP) is one of the largest Open Access journal publishers. It is currently publishing more than 200 open access, online, peer-reviewed journals covering a wide range of academic disciplines. SCIRP serves the worldwide academic communities and contributes to the progress and application of science with its publication.

Other selected journals from SCIRP are listed as below. Submit your manuscript to us via either submit@scirp.org or Online Submission Portal.
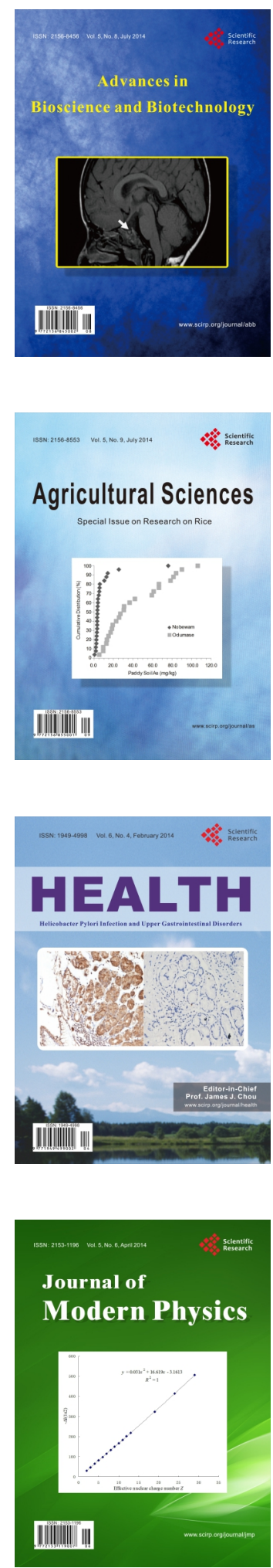
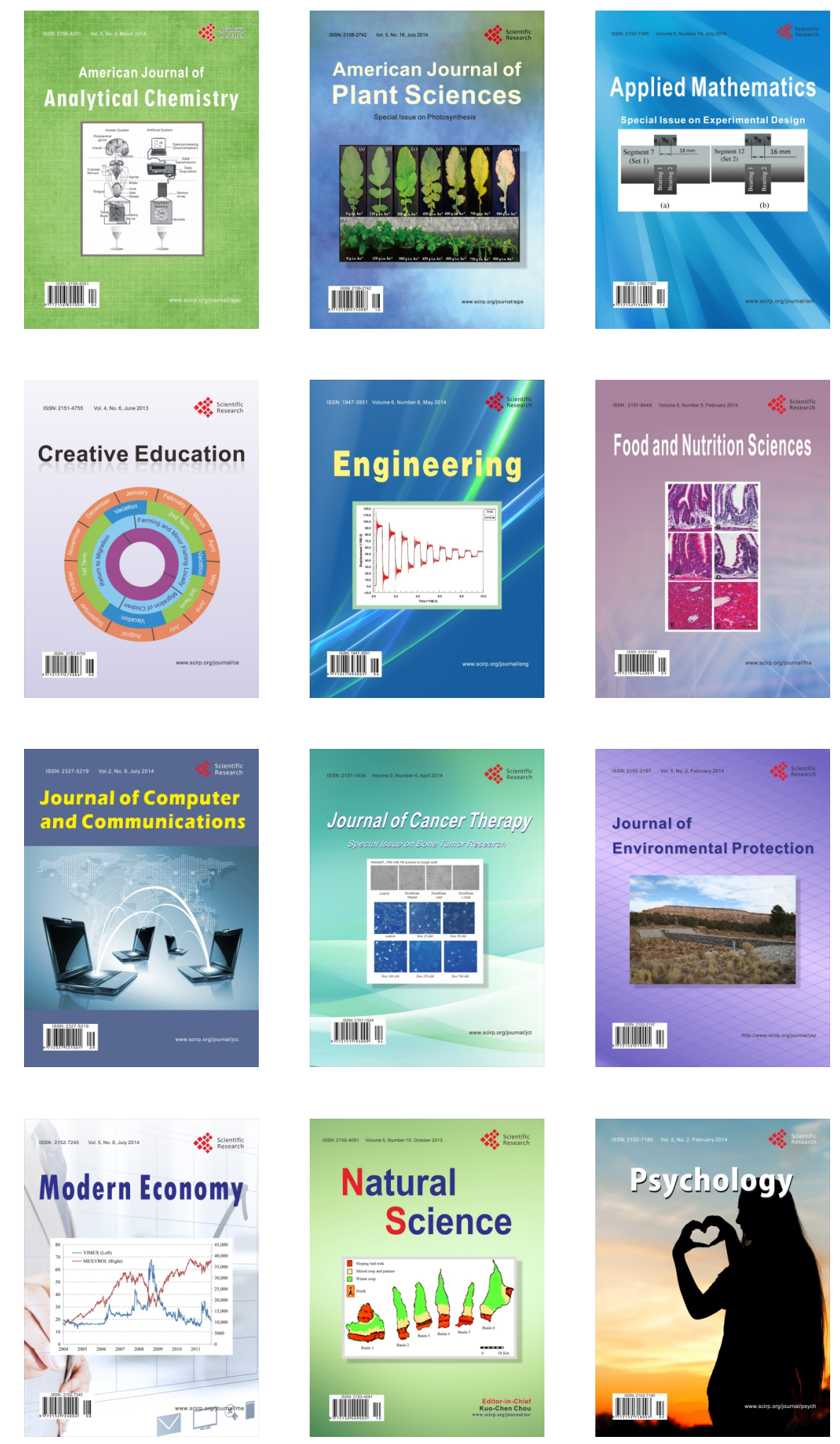